\title{
La Brevísima: el fantasma y el árbol del crimen
}

\section{The Brevísima: The Ghost and The Tree of Crime}

\author{
Enrique Flores Esquivel \\ Instituto de Investigaciones Filológicas \\ Universidad Nacional Autónoma de México \\ adugobiri@gmail.com \\ orcid.org/oooo-0oo2-7940-8142
}

Resumen: Este trabajo ensaya una aproximación a la obra más radical de fray Bartolomé de Las Casas - la Brevísima relación de la destrucción de las Indias - a través del sistema y la escritura del Marqués de Sade, y en particular a la luz de la lectura que hace de ella Roland Barthes en su libro Sade, Fourier, Loyola. Dicha iluminación coloca, paradójicamente, a Las Casas en la parte oscura de una tradición que se confunde con la llamada "leyenda negra", y puede definirse con el título que Barthes inicialmente dio a su ensayo: "El árbol del crimen". Este trabajo sobre el crimen, la puesta en escena y la crueldad se arraiga profundamente en el Barroco, y muestra a su vez múltiples conexiones con las técnicas de la imagen y la imaginación de Ignacio de Loyola.

Palabras clave: Las Casas, Marqués de Sade, Roland Barthes, Conquista, crueldad

\begin{abstract}
This work essays an approach to the most radical work of fray Bartolomé de Las Casas - A Short Account of the Destruction of the Indies - through Sade's writing system and, particularly, through the enlightenment of Roland Barthes' reading in his book Sade, Fourier, Loyola which paradoxically places Las Casas in the dark side of a tradition often confused with the so-called "black legend" that can be defined by the title Barthes initially gave to his essay: "The Tree of Crime". This work about crime, mise-en-scene and cruelty is deeply rooted in the Baroque, and also shows its multiple connections with the techniques of the image and imagination of Ignacio de Loyola.

Keywords: $\quad$ Las Casas, Marquis de Sade, Roland Barthes, Conquest, cruelty
\end{abstract}

Recibido: $\quad 5$ de junio de 2020

Aceptado: $\quad 26$ de octubre de 2020 
Tout plaît à la nature : il lui faut des délits.

Nous la servons de même en commettant le crime.

Plus notre main l'étend et plus elle l'estime.

Marqués de Sade, La verité

Se ha dicho a veces, como un argumento más para combatir el escándalo provocado por la obra de fray Bartolomé de Las Casas, que su mentalidad pertenece al Medievo y que sus ideas retrógradas riñen con la filosofía renacentista y la modernidad. ${ }^{1}$ Nada más lejos de la verdad. Como la herencia de esa obra lo muestra, la potencia viva de sus acciones y sus ideas es incontrovertible, y así lo prueba la resistencia que inspira en las luchas actuales de los pueblos indios. Pero su fuerza puede observarse desde otra perspectiva. En efecto, la figura del "buen salvaje", a la que frecuentemente se recurre para denostar al dominico, no solo puede remontarse a la antigüedad pagana, sino que es característica precisamente del llamado Siglo de las Luces y de la filosofía rousseauniana, para no hablar de Diderot y de su célebre Suplemento al viaje de Bougainville (2013). Pero existe otra cara de esa modernidad y de esa filosofía: lo que podría llamarse la "parte oscura" de las Luces. Toda una vertiente, toda una veta negra y criminal, en las antípodas de la Razón, latente en ese iluminismo de los filósofos y sumergida en los sótanos o calabozos del inconsciente, esos "castillos de la subversión" -o de la perversión-, según la expresión de la poeta Annie Le Brun (2008). "Parte oscura", "parte maldita" de las Luces, representada generalmente por el roman noir, pero, sobre todo, de manera extrema e incomparable, en su carácter pulsional y su furor radical y ateo, por el Marqués de Sade. No es que, por supuesto, Las Casas transgreda los límites de ese ateísmo, aunque al asomarse a los "abismos" de las pasiones humanas y su naturaleza criminal llegue a invertir en sus estampas y parodias crueles los ideales del cristianismo y de la religión, en los bordes del horror y el descreimiento, proyectando o vislumbrando en el límite, en ciertos momentos, un mundo sin Dios. De ahí el interés de leer a Las Casas a través de Sade, explorando la inhumanidad, la violencia ciega de la naturaleza, la "razón" sadiana, "la espuma de las leyes", su pensamiento-límite, el infinito de su "negación” y

1 La acusación forma parte, por ejemplo, de la larga letanía de estigmas arrojados por Menéndez Pidal en dos textos que "diagnostican" psiquiátricamente la "doble personalidad" del fraile dominico (Menéndez Pidal 1957 y 1963). Sobre este punto, $c f$. "Psycopathia lascasiana: un 'delirio paranoico'” (Flores 2021a). 
su "bloque de abismo", el "sistema de la agresión" o de la crueldad, el "árbol del crimen".2

\section{El árbol del crimen}

En su ensayo "El árbol del crimen",3 Roland Barthes investiga lo que en Sade, Fourier, Loyola llamará una "voluptuosidad de la clasificación", una "manía rabiosa de recortar", una "obsesión enumerativa”, una "práctica de la imagen”, una "costura del sistema social, erótico, obsesivo", común a esos tres "logotetas", a esos tres "fundadores de lenguas" (Barthes 1997: 9). Un "orden combinatorio", "inflexible", articula el discurso en todos ellos, y en especial el del Marqués de Sade, sea que se trate del descuartizamiento del "cuerpo de la víctima”, el cómputo de los "suplicios" o la infusión de la imagen en el "cuadro" violento de la orgía. ¿Y no sucede algo similar con las escenas de la Brevísima, cuya combinatoria incluye las variantes más "exquisitas" y extraordinarias de la "crueldad", cuya obsesión numérica ha llevado a sus críticos, escandalizados, a cancelar todo valor a la "relación" lascasiana, y a cuya "manía" repetitiva y fragmentadora - que parece deleitarse en cierto modo, aunque sea irónicamente, con una suerte de ironía macabra lindante con el nihilismo y nutrida por la negación, con esas imágenes capaces de "suspender el ánimo"

2 Aludo aquí, muy sintéticamente, a los extraordinarios trabajos sobre Sade de Maurice Blanchot ("La razón de Sade" (1990), con su énfasis en el "crimen infinito" y en la "negación") (1990) y de Annie Le Brun (Sade. De pronto un bloque de abismo) (2008), así como a la lección sadiana sobre la "espuma de las leyes" (abordada por Le Brun (2008), la compilación de los trabajos políticos de Sade en un volumen titulado Sistema de la agresión (1979) y el texto de Roland Barthes que servirá de referencia central aquí: "El árbol del crimen". Aclaro que el intento de este trabajo es iluminar la "relación" lascasiana con la reflexión suscitada en el semiólogo francés por la obra del Marqués de Sade, y no identificar la escritura o el pensamiento de ambos autores. Hay un exceso en Las Casas en el vínculo imaginario que propongo, y la lectura de la Brevísima admite otras ramificaciones derivadas de otras interpretaciones críticas de la obra del "Divino Marqués", incluida la de Klossowski (1970). Cf., en la bibliografía, mis otros trabajos sobre el tema, parten de una serie titulada: "Crueldad y conquista" (cf. Flores: "Homo homini lupus: el Hombre de los Lobos", 2019, Inflexiones, núm. 5: 9-33; "Psycopathia lascasiana: un 'delirio paranoico'", 2021a, Literatura Mexicana, núm. 32-1; "Zamé o la utopía”, LiminaR, 2021b [en prensa], núm. XIX-2 (juliodiciembre).

3 Publicado originalmente en la revista Tel Quel, ese ensayo se convertirá en el capítulo "Sade I", del libro Sade, Fourier, Loyola, al que nos referiremos, junto con su complemento: "Sade II", en esta aproximación. La traducción utilizada en este primer acercamiento es de Alicia Martorell, proveniente de la edición de 1997. 
y sumergir al escucha en el estupor, los extremos del "éxtasis" y la fascinación-, a cuya "manía", repito, debemos la acusación y hasta el diagnóstico psiquiátricamente fundado de "delirio" y "paranoia”?

Impersonal y sistemática, la "máquina de conquista" lascasiana obedece, a juicio de sus impugnadores, a una "regla única" y obsesiva, y él mismo se ocupa en reafirmar la validez universal de esta regla. Por eso el texto que la máquina genera, y que surge de una fuente originaria oral, en la célebre controversia de Valladolid, se aproxima al de aquellos "logotetas" de las pasiones, la santidad y la crueldad. Fetichismo, "ensamblaje" y "cuerpo fragmentado" articulan el texto y organizan los cuerpos en la "puesta en escena" del texto y de la conquista. Cuerpo individual y cuerpo social de "los indios", sometidos y sujetos a una violencia criminal: física, psíquica, biológica, metafísica, teológica, cosmopolítica. El discurso está sometido a "un Ordenador, un Maestro de Ceremonias, un Retórico", que en el caso de Sade "dirige la marcha general de la operación erótica" (Barthes 1997: 11), y en el de la Brevísima, las operaciones sangrientas de "conquista” y de "destrucción”. Pulsión erótica, pulsión de muerte: un mismo instinto libidinal-criminal, una misma sistematicidad. Pero el sujeto de cada "episodio" es solo un operador, y el texto solo "el ritual que ordena su placer" (11).

Hay un "éxtasis lascasiano" como hay un "éxtasis sadiano" en el interior de una suerte de "rito materialista [...] que no tiene nada detrás" (11). Y hay en ambos otra operación: la necesidad de formular —ritual, retórica, aritméticamente-y de "teatralizar". Más allá de la lamentada "monotonía del estilo", hay "insistencia" de la escritura. Como sucede en Sade, en la Brevísima opera una terca obstinación: "el sistema se deshace para convertirse en sistemática”; "la oración [se hace] obsesiva". Al fin "solo queda el escenógrafo: el que se dispersa a través de los soportes que va plantando y escalonando hasta el infinito" (Barthes 1997: 12). "Se prescinde del centro, del peso, del sentido": todos los crímenes se encadenan y queda solo la "diseminación" (13): fragmentación, formulación, proliferación (14); dispersión y destrucción "de todos los sujetos" (15). Lo que genera, según Barthes, un arrancarse de la ideología, un desprendimiento de las doctrinas, un borramiento de "la falsa eflorescencia, sociológica, histórica o subjetiva, de las determinaciones, visiones, proyecciones" (15), que las agencias y policías del orden imponen a textos que se colocan por encima, y en contra, de una sociedad y unas leyes. "Este exceso tiene un nombre", dice Barthes: "escritura" (17). 
Hasta qué punto o de qué modo puede decirse algo similar de Las Casas es algo que podría explorarse. Pues, si se aplica al autor el papel de "escenógrafo", puede pensarse la Brevísima como un escrito fragmentado, proliferante, diseminante y, en suma, atravesado — o agujerado - por el vértigo, la dispersión y la destrucción. Parece más difícil sostener, en un polemista como el fraile dominico, la postura de un escritor de combate que, justamente, podría definirse como ideológico y doctrinario. Y, sin embargo, no es tan extraño decir que, más allá del escándalo sin término suscitado por su obra, y en particular por la Brevísima relación, hay en ella en efecto un exceso que desborda su lectura histórica, social o psicológica, desde cualquier perspectiva que se asuma, sea la de un perpetuado orden colonial amenazado por ella, o la del "defensor de los indios"; la del agente responsable del tráfico de esclavos africanos en tierras amerindias; o la del antiguo encomendero que, convertido, pone en juego su vida y toda su potencia intelectual para enfrentarlas al poder de encomenderos y conquistadores. Y no es que haya que actuar como si esos elementos no existieran o no intervinieran en la génesis de sus escritos; pero estos sin duda los desbordan, los sitúan más allá de sus fines, más allá de la implementación de "nuevas leyes" y de la supresión de las antiguas: son un exceso en su despliegue vital, un exceso que podría llamarse: teatro de la crueldad.

No es mucho lo que Barthes apunta sobre el vínculo de Sade - y los filósofos de la Ilustración - con el colonialismo. Solo dice que "el viaje sadiano no enseña nada", que "la diversidad de las costumbres queda relegada a la disertación", que se viaja solo con el fin de "encerrarse" y que "siempre se trata de la misma geografía, la misma población, las mismas funciones; lo que importa no es recorrer contingencias exóticas, sino la repetición de una misma esencia, la del crimen" (Barthes 1997: 25). No hay exotismo en Sade ni en Las Casas, y es que la distancia tiene por objeto "aislar, proteger la lujuria [o las pasiones] de los recursos punitivos del mundo" (25), como en el castillo de Silling, o como en la Brevísima relación. Lo presume uno de los libertinos de Las ciento veinte jornadas de Sodoma: "Estoy solo aquí, estoy en el fin del mundo, lejos de todos los ojos y sin que pueda ser posible para criatura alguna llegar hasta mí; no hay frenos, no hay barreras" (apud Barthes: 26, n. 2). Todo pasa en "secreto", agrega Barthes, y el secreto telúrico es "un viaje a las entrañas de la tierra”: la visión "del volcán de Pietra Mala” (27), similar al Infierno de Las Casas ante el volcán de Masaya.

Hay una "puesta en escena minuciosa" en el texto sadiano, como la hay también en la Brevísima; hay una "economía de las pasiones": una "armonía" 
y una "utopía". Y es la "autarquía social", es esa libertad absoluta generada en la distancia del encierro - o en el "Nuevo Mundo"-, la que las hace posibles como sistema imaginario, como "sistema" y como "imaginación" (Barthes 1997: 27), no solamente en la "utopía" libertina sino en la "armonía" de los salvajes y en la "autarquía" conquistadora. Y si no existe, en "El árbol del crimen”, un vínculo entre el crimen y el colonialismo, sí hay una etnografía libertina, no relativa a los "salvajes" — como tampoco hay ciertamente una "etnografía" en la Brevísima -, sino a la propia etnia libertina: lo que Barthes llama en su texto la "etnografía de la aldea sadiana". Etnografía de la relación entre "esclavos y amos": dialéctica del cuerpo libertino, "signos de enormidad", de "monstruosidad", de "fábula", como en Las Casas; "gasto de esperma" y "orgías" - de sangre en el texto lascasiano, donde el "esperma" fluye solo en secreto, o de manera clandestina-, "pasión coprofágica", "lujuria" (2829). Desnudez inmediata de los cuerpos, que "no juega perversamente", y que, si en Las Casas representa un estado de naturaleza, en Sade -y entre los conquistadores - "solo sirve para marcar a las personas especialmente humilladas" (30). Pero lo principal en la etnografía sadiana, a diferencia de la dialéctica del amo y el esclavo en Las Casas, marcada por la dicotomía u oposición del "buen salvaje" y el bárbaro conquistador, es, de acuerdo con Barthes, la reversibilidad de los papeles de los verdugos y las víctimas - $\mathrm{o}$ los "sujetos de la depravación"-: "Todos los libertinos", dice Barthes, "son indistintamente sodomizantes y sodomizados" (32). Así se reduce la orgía a la combinatoria en que insiste todo el texto barthesiano, expulsando a su modo la violencia generalizada que la impulsa. Lo que es verdad, en cambio, igual que en Las Casas, es que el retrato de esos "sujetos de la depravación", o del exterminio, en la Brevísima, es "puramente retórico", puro "topos", pura "mitología” (32). Ese vaciamiento de sentido corresponde sobre todo a la víctima - aunque la "máquina de conquista" anula asimismo la identidad de los conquistadores-, víctima convertida en mero "signo vacío" (33), aniquilada en su ser mismo, reducida a la nada. "La sociedad sadiana no es cínica", dice Barthes: "es cruel". En ella, la desgracia es "espectáculo"; el "éxtasis" no contempla sino "la suma de los crímenes realizados" (34). Y aunque se apela a una reversibilidad, lo que separa a las víctimas de sus amos es la "voluntad de poder", o lo que Barthes designa como deseo de alcanzar "el dominio de la filosofía", el "libertinaje absoluto" (35). Así, la "etnografía" sadiana ha cedido su lugar a los "protocolos" de la sociedad libertina, cifrada en la "división" entre los libertinos y sus víctimas: una división "sin fundamento", apunta Barthes, 
que separa a dos clases que "son efecto de la división" y de una praxis (36). Y es en esa praxis del libertinaje y la conquista, la sujeción y la humillación, la aniquilación y la crueldad, donde, más allá de sí mismo, el conquistador se constituirá como "amo".4

Al margen de aquel giro lingüístico que Barthes quiere imprimirle al crimen -al árbol del crimen-, no es posible ignorar su acierto al hablar, así sea figuradamente, de un "lenguaje del crimen", o al postular que unas "reglas precisas" regirían en Sade "las acciones específicas de la lujuria", o al señalar que "la práctica sadiana está dominada por una gran idea de orden": al apuntar cómo "los desarreglos se organizan enérgicamente; la lujuria no tiene freno, pero sí orden" (Barthes 1997: 38). Y algo similar se aplica a la "máquina" de la Brevísima, donde una "regla única" e imperturbable regirá los infinitos relatos, ilimitados en sus variaciones, de la "destrucción de las Indias". Como la "combinatoria sadiana", las variaciones lascasianas están definidas por un "ordenador", una figura capaz de organizar los mecanismos de un lenguaje ya "no hablado sino actuado": por un "director de escena" (38). Por eso, más allá del "automatismo", la "escena sadiana" - y lo mismo diríamos de la "escena lascasiana"- produce una impresión de lo que llama Barthes “cronometraje”: "la escena está en marcha, el cuadro se dispone”, y se despliega una performance (39). El "lenguaje del crimen”, según el semiólogo, se configuraría a partir de una verdadera "gramática erótica" constituida por unidades o elementos que no sería difícil identificar al recorrer los distintos pasajes de la Brevísima: la "operación”, la "figura”, el "episodio", la "escena” y la "sesión", todas ellas sujetas a "reglas de combinación” o de "composición”, y a dos "reglas de acción" fundamentales: la de "exhaustividad", tendiente a la saturación de las "operaciones" eróticas y criminales, obediente al "carácter pánico del libertinaje" y del crimen, y la de "reciprocidad”, asociada a las figuras reversibles, al intercambio de las funciones, a la supuesta reversibilidad del sistema (40-42).5 No hay equivalencia entre las víctimas y los verdugos, sino una operatividad de las piezas en la acción del engranaje: lo que importa

4 Sobre la dialéctica sadiana, y sadomaquista, del amo y el esclavo, $c f$. la obra de Giorgio Agamben: El uso de los cuerpos (2017: 180-207). Para Barthes, esa praxis se reduce al final a una dimensión lingüística, semiótica.

5 A diferencia de la violencia conquistadora, en Sade, de acuerdo con Barthes, "no existe ninguna función reservada (con excepción del suplicio). En la escena, todas las funciones se pueden intercambiar, todo el mundo puede y debe ser por turnos agente y paciente, fustigador y fustigado" (Barthes 1997: 41). "Todo el mundo puede ser sodomita y sodomizado, agente y paciente, sujeto y objeto, ya que el placer es posible en 
es la operación de la "máquina" — como sucede en la Brevísima-. El "árbol del crimen" es un árbol lógico, generador de ramificaciones. Y si a menudo se le reprocha a Las Casas su obsesión y su exageración aritmética, "Sade no desdeñaba el algoritmo", y su "imaginación [...] es eminentemente contable". En suma, dice Barthes: en analogía con "los árboles gráficos de los lingüistas", lo que surge aquí es "el árbol del crimen" (40). Pero, en la raíz —retórica-de ese árbol, hay algo que lo nutre sin cesar, y es la palabra:

Salvo el asesinato, solo hay un rasgo que los libertinos poseen en propiedad y no comparten nunca, en ninguna forma: es la palabra. El amo es el que habla, el que dispone del lenguaje en su totalidad; el objeto es el que calla, permanece marginado, por una mutilación más absoluta que todos los suplicios eróticos, de cualquier acceso al discurso, pues ni siquiera tiene derecho a recibir la palabra del amo [...]. Existen víctimas - muy escasas - que pueden perorar sobre su suerte, representar al libertino su infamia [...], pero solo son voces mecánicas [...]. Solo [la] palabra [libertina] es libre [...].

En la sociedad sadiana, la palabra es quizá el único privilegio de casta irreductible. El libertino posee toda su gama, desde el silencio en el que se ejerce el erotismo profundo, telúrico, del "secreto", hasta las convulsiones verbales que acompañan al éxtasis [...]. La palabra se confunde enteramente con la marca confesa del libertino, que es [...] la imaginación: casi podríamos decir que imaginación es el equivalente sadiano de lenguaje (Barthes 1997: 42). ${ }^{6}$

De una manera quizá más radical, también las víctimas de la Brevísima, sujetas y reducidas a un topos "puramente retórico" y convertidas en "signos vacíos", carecen casi siempre de voz, son "el objeto [...] que calla [y] permanece marginado por una mutilación más absoluta que todos los suplicios" (Barthes 1997: 43) físicos a las que son sometidas —la mutilación, o la ablación, de la voz-: a excepción de unas cuantas ocasiones, como cuando, tiernamente, se evoca algunos de sus cantos, "solo son voces mecánicas". Y, sin embargo, allí tampoco es posible observar el "privilegio irreductible" —que existe- de la "palabra del amo", ni escuchar el silencio telúrico del volcán o del "secreto", ni las "convulsiones verbales" del éxtasis. Es a otro nivel que se ejerce ese dominio allí, en la "máquina" despersonalizadora de conquista.

todas partes, entre las víctimas y entre los amos" (42). Cf. Acerca de los usos sadomasoquistas del cuerpo, $c f$. Agamben (2017).

6 Sobre la imaginación, $c f$. más adelante la reflexión barthesiana sobre el "método" fantasmático de Loyola. 
La "palabra del amo" es la del autor del discurso; el silencio y la convulsión se extienden a través de la escritura - que antes fue habla - como vértigo generalizado y devastador, proliferan y se contagian a través del discurso y la historia y a partir de la voz del dominico que reproduce y multiplica hasta la saciedad las violencias, las crueldades y las conquistas de esos agentes de maldad e inhumanidad, en cada escena, cuadro o sesión, conforme a un "orden retórico", al orden perverso y fantasmático de la "imaginación", de una "máquina" que, "mucho antes de Freud", y mucho antes de Sade, convierte no solo al "esperma" sino a la sangre — sangre que es esperma - en "sustituto de la palabra" (43).

Como en la Brevísima, cuyo "Argumento" alude también a las "tan admirables y tan no creíbles" hazañas de las Indias y a su "maravilloso descubrimiento", se convierte a la "red del crimen" en "árbol maravilloso". "Nace el árbol del crimen", dice Barthes. Hay una "contaminación" recíproca de "la erótica y la retórica, la palabra y el crimen” (Barthes 1997: 44). Y "la contaminación criminal llega a todos los estilos del discurso: narrativo, lírico y moral, la máxima, el topos mitológico" (45). Paradójicamente, en esa contaminación radicaría la condición poética de una escritura "vinculada con el crimen y el sexo", y de una escritura en última instancia - como sucede en la Brevísi$m a$ - irrecuperable: "No solo la escritura de Sade es poética, sino que Sade ha adoptado todas las precauciones para que esta poesía sea irrecuperable" (45-46). Esa condición no solo es posible por el carácter extremo de la escritura sadiana -o lascasiana - sino porque, en el interior mismo del libro, "existe otro libro, libro textual, tejido de pura escritura", dice Barthes, aunque en realidad ese "tejido" trama también otras voces, muchas voces, y la voz del "amo" o del "escenógrafo" que las ordena se desdobla en sí misma con un doble efecto que desborda al autor -apócrifo - que organiza y desorganiza el discurso: de compasión y de crueldad, de escándalo ante la injusticia y de goce cruel que desborda, también, a su modo, el cálculo del expositor. Esta trama del segundo libro "determina todo lo que ocurre 'imaginariamente' en el primero", dice Barthes: "no se trata de relatar, sino de relatar lo que se relata" - o de otro modo: no se trata de escribir la historia de la Conquista, sino de relatar o de hacer la relación de las "conquistas", y si en Las ciento veinte jornadas de Sodoma, "toda la sociedad sadiana [...] está volcada hacia la historia", toda la sociedad conquistadora está volcada hacia el relato entendido también como historia, como relación, como secuencia imaginaria - hecha de imágenes- o como "imaginación” objetivada. Y la misma ejemplaridad 
alcanza también a ambos textos: las escenas y acciones son "ejemplos", señala Barthes, "gramaticales y de depravación", "la práctica sigue a la palabra y recibe de ella su absoluta determinación". "Lo que se hace ha sido dicho. Sin la palabra formadora, la depravación, el crimen, no se podrían inventar, desarrollar: el libro debe preceder al libro, la narradora [o el narrador o 'author' de la 'relación', en la Brevísima] es el único 'actor' del libro, pues la palabra es su único drama" (Barthes 1997: 47).

La obra de Sade, como la de Las Casas, ha sufrido innumerables prohibiciones o "interdictos", que a menudo, dice Barthes, agregan a la reprobación moral -o política - una motivación estética. ${ }^{7}$ Una de las más reiteradas es la acusación de "monotonía" - a la que se añade la repetitividad, muy acentuada en la Brevísima - , y otra la de "irrealidad”, una de las invectivas más malévolas y frecuentemente lanzadas contra el dominico. Ambas condenas apelan a un "realismo" fundado en la idea de la escritura como "representación", en el sentido no teatral del término, es decir, como reflejo de la realidad y no como puesta en escena. Y si la condena por "monotonía" apela, dice Barthes, al "mito romántico de la inspiración", la sanción por "irrealidad" es condena de lo "fabuloso", de lo "imposible":

En cada página de su obra, Sade nos da pruebas de "irrealidad" concertada; lo que ocurre en una novela de Sade es claramente fabuloso [...] imposible; o más exactamente, las imposibilidades del referente se transforman en posibilidades del discurso, se desplazan los límites: el referente queda totalmente a discreción de Sade, que puede darle como cualquier relator dimensiones fabulosas, pero el signo, que pertenece al orden del discurso, es intratable, es el que dicta la ley.

Por ejemplo, Sade multiplica en una misma escena los éxtasis del libertino más allá de todo lo posible: [...] más vale multiplicar los éxtasis (Barthes 1997:48).

Se dirá que, a diferencia de Sade, la Brevísima no es obra de "ficción", aunque la de Sade es también obra filosófica y ensayística, polémica y política. Como, por ejemplo, su célebre manifiesto - “Franceses, un esfuerzo más si queréis ser republicanos"-, obra en el fondo de invención e imaginación.

7 La más notoria de esas críticas, por la autoridad de quien y por su carácter desmesurado (tan desmesurada como los excesos que denuncia) es la de Ramón Menéndez Pidal, primero en su artículo: "Una norma anormal del padre Las Casas" (1957), y después en su libro: El padre Las Casas: su doble personalidad (1963). Para un análisis detallado del primero, $c f$. mi artículo "Psycopathia lascasiana: un 'delirio paranoico" (Flores 2021a). 
Pero tampoco se trata de reducir a Las Casas ni a la fantasía delirante de un fanático o un alienado, ni a la mala fe de un historiador "falaz", ni a la expresión exagerada o monstruosa de un "literato" poseído. La clave es la potencia de la imaginación: la indetención ante la "irrealidad" que revela la pobreza de la realidad, o de nuestra percepción de la realidad; la irrupción de lo imaginario como fuerza lógica, y a la vez anómala, centrífuga, fabulosa, imperturbable, conmovedora y vital que expresa la verdad de un acontecimiento - el de las "conquistas" - desquiciante y aniquilador, y eso, en los términos de una escritura que moviliza continuamente sus límites, hasta el extremo de "lo imposible", como quería Bataille - en una obra titulada al principio, precisamente, "El odio de la poesía"- - La miseria positivista de los historiadores sale aquí a relucir. Lo mismo que la ceguera de los literatos ante un libro fundamental, como los del Marqués de Sade. Y todo eso, como dice Barthes, frente al "orden del discurso" y contra lo que "dicta la ley". En suma, y en términos semiológicos: el discurso contra el referente y la semiosis contra la mímesis, la performance monstruosa contra el cristal de la representación (48):

La función del discurso no es, efectivamente, "dar miedo, vergüenza, deseos, impresión, etcétera”, sino concebir lo inconcebible, es decir, no dejar nada al margen de la palabra ni conceder al mundo nada inefable: tal es al parecer la consigna que se repite a lo largo de toda la sociedad sadiana, desde la Bastilla, donde Sade solo existió gracias a la palabra, hasta el castillo de Silling, santuario, no de la depravación, sino de la "historia” (Barthes 1997: 49).

\section{Ramificaciones}

En su segundo trabajo sobre el Marqués de Sade — “Sade II"-, Barthes retoma muchos de los puntos abordados en "El árbol del crimen". Revisarlos un tanto deshilvanadamente puede ayudar a visualizar con una luz más intensa los mecanismos de la máquina sadiana, sin intentar buscar ya las analogías con la "máquina de guerra" lascasiana, aunque no deje de alumbrarla en su funcionamiento poético, retórico, teatral, óptico, narrativo, teológico, político, criminal, pasional y escritural, que el lector podrá a solas desprender del texto.

Entre las notas que organizan este segundo ensayo destacan las que se refieren a la composición del texto. En primer sitio, sus impossibilia: "al imaginar las actitudes de la depravación, Sade defiende imposibilidades" (Barthes 1997: 158). La escena sadiana —y la misma acusación recurrente ha sufrido 
la escena cruel de la Brevísima - aparecería como "fuera de toda realidad", marcada por una "inverosimilitud" física y anecdótica que depende, en realidad, del "poder del discurso", específicamente del "poder de negación" del discurso. "El lenguaje tiene una facultad de negar, de olvidar, de disociar la realidad", y da cuerpo, así, al libertinaje - y a la crueldad- "como un acto del lenguaje", como una instancia de la "realidad del lenguaje" (159-160). La obsesión lingüística de Barthes entronca aquí con la intuición o percepción de un texto que se construye en "disociación", como "negación" aparente de la realidad, y que en realidad opera un acercamiento a lo Real insoportable. La retórica sadiana es "una máquina del deseo" (162) y crea una "estructura rapsódica de la narración”, que consiste en el montaje o la yuxtaposición pura y simple de "fragmentos iterativos y móviles" —a la manera de la Brevísima-, cuya continuidad se reduce a "una serie de piezas yuxtapuestas, un tejido barroco de harapos" (163). Curiosa analogía la del "barroco plebeyo" que aparece en la "rapsodia" libertina del deseo, pues, como en el auto sacramental barroco, aunque Barthes la remita al "espectáculo medieval" - los misterios teatrales, tal vez-, la "parodia ignominiosa" del sacramento de la penitencia consumada, en una orgía, por Sade se resuelve en una extraña y perversa "estereografía”: "el libertino ve y escucha simultáneamente [en escena] lo que está separado por la teología, a saber, el Alma y la Carne” (168-169). La escena teológica se extiende a la escena pornográfica, en un gesto deseado por Klossowsky, de una manera que trae a la mente ciertas escenas de la Brevísima: crueles parodias conquistadoras de los misterios divinos. Y asimismo al modo del Barroco, aunque no lo apunte Barthes, "en este teatro" - como en la Brevísima, cuyas crueldades "encubren" los nombres y los rostros de sus agentes, y donde se confunden las figuras del acusador y el acusado, el defensor profético y el conquistador, dada la antigua condición de encomendero del fraile dominico-, "todo el mundo es actor y espectador"; el espacio de la mímesis se extiende al de la praxis; "la historia relatada se convierte en el programa de una acción”; las "unidades de la combinatoria, los elementos del sistema" se ordenan "alrededor del Trono", y "lo que se alza en el trono es la Palabra" (170). Todo ello acorde con la ordenanza del "Epítome" lascasiano en torno a un diálogo con el rey.

Barthes vuelve a aludir en sus notas a la "obsesión" numérica que rige al texto de Sade y se conecta con el montaje y la aludida "yuxtaposición", o "superposición": "No se trata tanto de multiplicar los placeres, de hacerlos girar [...], como de superponerlos" (Barthes 1997: 181). Ahí radica el "placer", dice 
Barthes, de la "aritmética sadiana" - que en la Brevísima no sería un "placer", sino un goce perverso: las "infinitas" y "exquisitas especies de crueldad"-_:8 adición, suma, acumulación, pues "la suma de los placeres es un nuevo placer [...], el de la acumulación misma; la adición se convierte a su vez en una unidad que se suma a sus componentes", y ello en el marco de un "placer superior, meramente formal porque es [...] solo una idea matemática, un placer del lenguaje" (181). Lo que la crítica historicista y la psicopatología positivista denuncian como exceso delirante, aparece como virtud del texto bajo la óptica de la escritura, en su función de alumbramiento o iluminación, ante el volcánico e infernal abismo que se abre en las tierras de conquista. Pues si se acepta esa imaginación -la producción libre de imágenes - como una dimensión fundamental de la escritura, y el delirio aritmético se vuelve una intensificación de sus principios, como si la disociación escritural alcanzara el summum de su potencia al liberarse de las cadenas del "realismo", extremándose a su vez en el texto, sería posible aceptar asimismo el papel de la "fantasía" en la imaginación libertina como en la conquistadora. Y es que, apunta el semiólogo, la "escena de lujuria" está precedida y formada por una "escena de escritura”. "Todo sigue el dictado de la fantasía: ella lleva la batuta" (187). "La fantasía es dictator: todo está en juego en este dictado". Y todo dictado supone - como supo comprenderlo Augusto Roa Bastos, autor de Yo el Supremo, al esbozar la figura despótica del Supremo Dictador - la "huella profunda de un texto anterior" (189), como sucede justamente en el caso de la Brevísima, escrita a partir de una escritura anterior y de la huella de un discurso oral anterior, y dictado a la vez de la escritura sobre los actos y acontecimientos en devenir, conforme a la regla que dictamina desde un principio en la obra lo que sucederá. "Solo queda una inscripción cuyo tiempo es múltiple", y "el tiempo de la escritura gira" (189).

Otra línea que siguen las notas del segundo ensayo de Barthes es la que se refiere a la "máquina del deseo". "La orgía está organizada, repartida, controlada, vigilada como una jornada de taller", como un "trabajo en cadena", y lo que describe "en realidad, Sade, es "una máquina", "la Máquina como emblema sublimado del trabajo", en la que "todo el mundo forma un inmenso y sutil engranaje, un mecanismo de relojería fina, cuya función es darle trabazón al placer, producir un tiempo continuo" (Barthes 1997: 147-148). La figura

8 Cf. Las Casas (65), así como mis ensayos vinculados, y en especial: "Homo homini lupus: el Hombre de los Lobos" (Flores 2019). 
maquínica, con ese frío mecanicismo abstracto que representa el semiólogo, no aparece en Las Casas, aunque la Brevísima opere como una "máquina de guerra", de destrucción y de conquista. Sin embargo, vale la pena seguir hasta el final la analogía, visualizar las consecuencias de esa óptica conducida a la escena violenta de la orgía. Así, dice Barthes, "Sade inventa con frecuencia verdaderas máquinas, voluptuosas o criminales" (175). Y no se trata solamente del autómata: "todo el grupo está concebido, construido, como una máquina", definida por "el encadenamiento de todas las piezas", y que, "una vez en funcionamiento, tiembla y susurra ligeramente con los movimientos convulsivos de los participantes" (176). Visto de otro modo, "el grupo sadiano [...] es un objeto pictórico o escultórico: el discurso capta las imágenes de la depravación", dice Barthes, "no solo organizadas, arquitecturadas, sino sobre todo congeladas, enmarcadas, iluminadas", como "cuadros vivientes", o verdaderos tableaux vivants (177). Kitsch estético del rococó posbarroco —cuya versión visual y pornográfica ofrecen los grabados que ilustran las novelas de Sade, que tan enfáticamente muestran la dimensión mecánica o maquínica de la orgía, de "trabajo en cadena"-, muy alejado por cierto de la imaginación de la Brevísima, mucho más vinculada, lo veremos, a la "óptica" loyoliana, al sistema de producción de imágenes de los Ejercicios espirituales, no en su mántica espiritualista, sino en su vinculación con el deseo y el fantasma.

La "máquina del deseo" sería, por fin, como la orgía, una máquina silenciosa:

Aparte de los gritos de las víctimas, aparte de las blasfemias, que pertenecen, unos y otras, a la eficacia del ritual, se impone un profundo silencio a toda escena de lujuria [...]. Este silencio es el de la máquina lujuriosa, tan bien lubricada, con un rendimiento tan ligero que distinguimos algunos suspiros, temblores [...]. La orgía sadiana es silenciosa (Barthes 1997: 190-191).9

9 A diferencia del "fotograma fílmico" - y me interesa recalcar la apariencia de montaje cinematográfico que revisten los cuadros y las escenas de la Brevísima-, que se enfrenta a la película como una "fractura" del orden de la "perversión" y el fetichismo del "objeto" (parcial), como un "fotograma de la depravación", el "cuadro viviente" progresa, en Sade, hacia lo que el semiólogo llama la "escena en marcha": una escena que funciona como "una máquina sin sujeto", con "puesta en marcha automática", ante la cual hay siempre un espectador que, "dejando su sillón, su galería, su patio de butacas, sube al escenario, entra en la pantalla, se incorpora al tiempo, a las variaciones y a las rupturas del acto lúbrico, en una palabra, al juego: se pasa de la representación a la actividad" (Barthes 1997: 178). Sade pasa del "cuadro viviente a la escena (a la escenografía)". Lo que a Barthes le trae a la memoria ciertas cajas de música suizas llamadas 


\section{Teatro, fantasma, deseo}

La conexión de Las Casas con Loyola pasa por las formas y el sistema de producción de imágenes a través y como efecto de la escritura. Parece interesante, entonces, continuar la lectura semiológica de Barthes más allá de "El árbol del crimen", y a la vez regresando en el tiempo, a la época del fraile dominico - los Ejercicios se publicaron en el año de 1548, la Brevísima en 1552, aunque ambos libros abrieron un futuro imprevisto y divergente-, y, más allá del tiempo, a las raíces o las fuentes del fantasma y el deseo. ${ }^{10} \mathrm{Y}$ es allí, en la imaginación generadora justamente de imágenes, fantásticas o no, donde es posible ver la raíz de la exuberancia lascasiana de imágenes y la índole infernal de esas imágenes.

"Lo imaginario de Ignacio es muy pobre" (Barthes 1977: 56), señala Barthes en un apartado titulado "La imaginación". Y añade: "La red de imágenes de que él dispone espontáneamente [...] es más o menos nula” (56). Una "técnica encarnizada" servirá para ofrecerle imágenes "al que está desprovisto de ellas de forma congénita", pero estas imágenes "siguen siendo banales y esqueléticas: si es preciso 'imaginar' el Infierno [...] será con incendios, aullidos, azufre, lágrimas" (56). "Recuerdos de una discreta estampería”, dice Barthes, aunque también se podrían atribuir a la impactante tradición plasmada en los murales del Juicio Final o en la imaginería escatológica que aterroriza a los creyentes con el espectáculo — tópico, quizá, aunque infinito en sus repercusiones- del Apocalipsis o las penas infernales. Justamente se ha acusado a Las Casas de cifrar la crueldad de la Conquista en imágenes como esas, a la vez desmesuradas y arquetípicas, ${ }^{11}$ sin pensar en la inmensa generación de imágenes que late en esos acontecimientos — las innumerables e infinitas "conquistas" - cuando se los concibe de manera plural y sistemática, rizomática se diría. Imágenes reales y a un tiempo obsesionantes, que parece imposible erradicar de la memoria y alientan la imaginación de un modo incomparable. Lo cual coincide con otro apunte de Barthes: "Mientras más nulo es

\footnotetext{
“cuadros mecánicos", en los que algo "se podía animar mecánicamente”, y que es como el "estado arcaico" de la escena sadiana (179).

10 A diferencia de los ensayos sobre Sade, mi lectura del ensayo sobre Loyola parte de la primera traducción de Sade, Loyola, Fourier (1977), que hace uso de la palabra fantasma en vez de referirse a la fantasía.

11 La desmesura, la desproporción, la exageración, la megalomanía son aspectos alegados recurrentemente, como síntomas de "anormalidad" psiquiátrica, por Menéndez Pidal en sus invectivas contra Las Casas.
} 
lo imaginario de Ignacio, más fuerte [...] es su imaginación" (57). ${ }^{12}$ Y es como energía de fabricación de imágenes, como "energía de la palabra”, que, con el fin de intensificarse y concentrar la fuerza de sus imágenes, que la imaginación se proyecta como una función "interior", mágica o apotropaica, como "poder de rechazar las imágenes extranjeras”:

Ella forma un ars obligatoria que decide menos lo que es necesario imaginar que lo que no es posible imaginar -o lo que es imposible no imaginar-. Es ese poder negativo el que es preciso reconocer [...] en ese acto fundamental de la meditación que es la concentración: "contemplar", "determinar", "representarme con ayuda de la imaginación", "ver con los ojos de la imaginación”, "ponerme frente al objeto" (Barthes 1977: 57).

La exclusión, la eliminación de aquello que no constituye la fuerza, la intensidad de la imagen —en una suerte de descontextualización de la imagen, o de separación de la imagen, y lo imaginario, de lo aparentemente "real"-, es la primera "ley" loyoliana de la producción de imágenes de meditación, por cierto, íntimamente vinculada a otro tema que Barthes presenta como "una forma ligeramente variada de esta ley de exclusión" (Barthes 1977: 57), y que es "la obligación que tiene el ejercitante de ocupar todos los sentidos fisiológicos (la vista, el olfato, etcétera), consagrándolos sucesivamente a un mismo tema" (57). Una "técnica" se sintetiza en estas dos variantes de la ley de la imaginación, precipitando - de manera casi alquímica - una imagen más "real" que las imágenes de la realidad aparente, plantada en un mundo imaginario, irreal pero tangible, que es posible mirar, contemplar, olfatear, oír, tocar con la intensidad que ofrecen las percepciones sensibles de la experiencia cotidiana, con aquella impronta casi física con que se imprimen las imágenes, por ejemplo, del "arte de la memoria" tan fantásticamente estudiado por Frances A. Yates: imágenes grotescas u obscenas, violentas o sangrientas, extáticas o criminales que se graban en la memoria por esa misma peculiaridad (Yates 1974). Hay que pensar las imágenes de la Brevísima en el espíritu de esa nueva "retórica" visual, de esa nueva "ortodoxia de la imagen" inaugurada por los Ejercicios, aunque proyectada por Las Casas en una dirección muy distinta, ya no "meditativa" únicamente sino conmocionante, catártica, capaz de

12 Más “incansablemente cultivada”, apunta entre paréntesis, como aludiendo a un lujo que se "cultiva". 
trastornar y "suspender el ánimo", o conducir al éxtasis —como imaginaba Artaud (2014) — por la vía de la crueldad.

La "imagen" loyoliana, como la lascasiana, no sería una "visión", anota Barthes, sino una "vista", "en el sentido que ese término tiene en el arte del grabado" (1977: 61). Apunte que, en el caso de la Brevísima, ampliamente difundida a través de las estampas o grabados de Theodor de Bry, el artista flamenco, resulta altamente pertinente, ya que no solamente sus efectos de contaminación o contagio - en la génesis de la llamada "leyenda negra" - se producen inequívocamente a partir de las imágenes plasmadas por aquel en sus grabados, sino que la obra en sí misma llevaba la semilla de esa verdadera diseminación imaginaria, en su recurso al impacto de las imágenes visuales generadas por la propia escritura como técnica de conocimiento, más allá del argumento y el estilo. Y esas vistas, dice Barthes, hay que tomarlas "dentro de una secuencia narrativa", como pasa con las series pictóricas o las "ilustraciones sucesivas de una novela", algo que en la Brevísima da la impresión de extremarse hasta el límite de esbozar, por la velocidad misma y el ritmo de la sucesión de las escenas, no solo un montaje escénico sino una auténtica secuencia cinematográfica. Y aunque esas vistas extienden su significado hasta reunir, según el semiólogo, "todas las unidades de la percepción imaginaria", y figuren "sabores, olores, sonidos o sensaciones" simultánea o sucesivamente, "es la vista visual", si es posible decirlo así, "la que recibe todos los cuidados de Ignacio". La "sugestión" de esas imágenes precede a todo ejercicio: es la célebre "composición viendo el lugar" —-fundamental en la Brevísima -, cuya doble tradición se remonta a la topografía como técnica retórica y a cierta tradición cristiana:

Tradición que rechaza, por lo demás, Teresa de Ávila, incapaz, decía, de hacer trabajar su imaginación sobre lugares determinados, pero que Ignacio sistematizó al punto de querer publicar, al final de su vida, un libro en el que las composiciones de lugar habrían sido figuradas, grabadas [...] (en el siglo XviII, el manual de Ignacio fue ampliamente ilustrado) (Barthes 1977: 61-62).

Ese ascetismo místico de Teresa de Ávila contrasta con la "tecnología espiritual" de Loyola, aunque, en la práctica, ocupe una "posición intermedia” entre Juan de la Cruz, para quien "imágenes, formas y meditaciones convienen tan solo a los principiantes", y el fundador de la Compañía, en lo que se refiere a la "imaginación" (Barthes 1977: 72). Si "desde un punto de vista 
místico, la fe abisal es oscura, está inmersa o se ha ido a pique (dice Ruysbroeck) en las inmensas tinieblas de Dios" (61), Loyola responde con un auténtico "imperialismo de la imagen" - "imperialismo" que no deja de resonar en las aspiraciones de la Brevísima-:

Ignacio responde a estas desconfianzas, místicas o ascéticas, por medio de un imperialismo radical de la imagen: producto de la imaginación dirigida, la imagen es la materia esencial de los Ejercicios, las vistas, las representaciones, las alegorías, los misterios (o anécdotas evangélicas), continuamente suscitados por los sentidos imaginarios, son las unidades constitutivas de la meditación, y como se dijo [...], ese material figurativo engendró con mucha naturalidad, después de la muerte de Ignacio, una literatura de ilustraciones, grabados, que a veces se adaptaron al país en cuya evangelización debían ser útiles: al último emperador Ming le ofrecieron algunas (Barthes 1977: 73).

Esta última imagen del emperador Ming, recibiendo de manos jesuitas imágenes generadas por los Ejercicios, parece especialmente reveladora. Pues si Theodor de Bry, el grabador flamenco, compuso sus “imágenes" teniendo a la vista las crónicas publicadas entonces en Francia, Alemania, Inglaterra y los Países Bajos - la Brevísima se publicó en Amberes, en su versión francesa (1579), y luego en sus versiones inglesa (1583), alemana (1597) y latina (1598), todas ellas con los grabados de De Bry-, lo hizo sin haber pisado nunca las Indias, creando en consecuencia, en cada una de ellas, un lugar correspondiente a un "espacio imaginario" generado por la propia escritura de las crónicas aunque alejado de la "realidad": espacio cruento y visceral, propicio a la fantasía y al ansia y deriva de lo Real; imperialista y colonial, como el Imperio cuyas crueldades se deseaba "revelar", y tan irreal como visibles y palpables eran los fantasmas que hacía aparecer. En cuanto a la Brevísima, no extraña ver a Las Casas combatiendo "encomiendas" y "conquistas" con las armas de la Contrarreforma, disputando ante el trono el control del imperio, llamando al rey a disolver o desautorizar esas prácticas y a crear nuevas leyes, aboliendo las otras, apelando a una nueva "tecnología de la imagen" - atenta siempre al "lugar", a la "vista”, a la convocación simultánea de todos los sentidos y a la "composición viendo el lugar" - . Las Casas viendo el lugar: esa es la escena que revela el vínculo imaginario con Loyola, y esa es la "América imaginaria" que se "revela" en el sentido casi fotográfico de "escritura de la luz y las sombras": arcádica y edénica con los indios, cruel con la "leyenda negra”. 
En ese magma imaginario que organiza la "materia esencial de los Ejercicios", y en las que se entremezclan y se combinan las vistas y las representaciones, las alegorías y los misterios_-“anécdotas evangélicas", señala Barthes, como las anécdotas grotescas o paródicas que perforan a la Brevísima-; en la múltiple "arborescencia" de ese "árbol" de vínculos y "bifurcaciones" o "ramificaciones" que crecen en "extrema complejidad" (Barthes 1977: 63), en ese "árbol de Ignacio", tan aparentemente distante del "árbol del crimen", aunque en el fondo no lo sea, hay un "aparejo suplementario", una infinitud de posibilidades cifrada en una tópica, esa parte de la inventio reservada a los "lugares comunes", cuyas "listas", apunta Barthes, son los diez mandamientos, los siete pecados capitales, las tres potestades del alma, y sobre todo los cinco sentidos. Esa es la imaginería ignaciana, tan cercana a las técnicas de Las Casas: "ver los cuerpos incandescentes, oír los gritos de los condenados, oler la cloaca del abismo o gustar la amargura de las lágrimas, tocar el fuego" (64-65).

Tales son las "listas" de Loyola, no tan distantes del Infierno de la Brevísima. Y ya que me he referido al montaje, dos tipos de ensamblaje aparecen, dice Barthes, en la práctica de los Ejercicios: "la repetición y el relato". La repetición - recurso muy común, asimismo, en la Brevísima - puede ser "repetición literal", o rumiadura, summatio o "recapitulación”, y "repetición variada", que consiste en volver a comenzar una y otra vez un tema "cambiando su punto de vista" (66). En cuanto al relato, Barthes se refiere a "las meditaciones elaboradas por Ignacio a partir de un corte del gran relato evangélico, cuyos episodios se dan al final de los Ejercicios bajo el nombre de misterios" (66) —otros cortes y misterios de este mismo "gran relato evangélico", grotescamente transfigurado, balizan la Brevísima-, y señala que, como en la Relación de Las Casas, "podemos aumentarlas o dilatarlas", y "poseen [...] el atributo patético de la estructura narrativa: el suspenso" (66). Es en virtud de ese pathos del relato - que en la Brevísima tiene la función de producir "una manera de éxtasis y suspensión de ánimos, con exquisitas especies de crueldad" (65) - que "es posible dramatizar su repercusión, reproduciendo en sí la forma del suspenso" y haciendo "que la sombra se disipe de un modo tardío o incierto", apunta Barthes. Así, al relatarse la historia de Cristo -o las crueldades de las "conquistas", que convierten a sus víctimas en "ovejas", figuras evangélicas-, "el ejercitante no debe apresurarse, debe agotar cada una de sus estaciones, hacer cada 'ejercicio' sin tener información del siguiente, no dejar que acontezcan demasiado pronto, o fuera de lugar, movimientos de consuelo; en una palabra, respetar el suspenso de los sentimientos, si 
no el de los hechos" (Barthes 1977: 67-68). Esta descripción, tan compleja y detallada, que el semiólogo desprende del texto de los Ejercicios, coincide punto por punto con la violenta, convulsiva, "meditación" de las escenas de la Brevísima.

El misterio teatral, el ejercicio, desembocan en la técnica del psicodrama:

Es en virtud de esa estructura narrativa que los "misterios" delineados por Ignacio en el relato crístico tienen algo teatral que los emparenta con los misterios medievales: son escenas que al ejercitante se le pide vivir, a la manera de un psicodrama. En efecto, al ejercitante se le exige invertirse tanto en el relato como en la repetición. Él debe repetir lo que, en cada relato, lo deprime, lo consuela, lo traumatiza, lo encanta; debe vivir la anécdota identificándose con Cristo: "demandar en la pasión dolor con Cristo doloroso, quebranto con Cristo quebrantado". El ejercicio implica fundamentalmente un placer [...], y el teatro ignaciano es menos retórico que fantasmático: la "escena" es allí, en realidad, un "guion" (Barthes 1977: 68).

La técnica ignaciana de la imagen, con toda su complejidad, corresponde a la era de la Contrarreforma, a la que Barthes no alude pero que se vincula con lo que el título de otro capítulo designa: la "Ortodoxia de la imagen". Pues, si en la Edad Media, "el sentido más afinado" era el oído, y la vista venía en tercer lugar, después del tacto, más tarde "hay un trastrocamiento: el ojo se convierte en el órgano mayor de la percepción”, como habría de atestiguarlo "el Barroco, que es el arte de la cosa vista" (Barthes 1977: 71). Frente a ese "imperio" de la imagen, había sin embargo "resistencias" de orden religioso como las de san Juan de la Cruz y santa Teresa de Ávila, de origen místico, y otras más tradicionales, pero la imagen era vista como algo "anterior al lenguaje" que agitaba en su interior algo bárbaro, algo natural, en suma, que la volvía sospechosa frente a toda "moral disciplinaria" —idea al menos discutible, pues justamente los Ejercicios eran una técnica o disciplina espiritual de nuevo cuño, una nueva modalidad disciplinaria, aunque efectivamente vinculada a esa naturaleza primitiva o bárbara que se proyecta en lo "prelingüístico", y de otra manera, en las crueles escenas inefables, suficientes para sumir en el silencio de la Brevísima-. Y quizá lo que se cifraba como peligro de la imagen era "el presentimiento de que la vista está más cerca del inconsciente y de todo lo que en él se agita, como Freud lo notó” (72).

¿Psicodrama, fantasma, inconsciente? Una enorme energía pulsional impulsa las imágenes de la Brevísima en su sucesión, su yuxtaposición, su 
detención y su aceleración: en su puesta en escena y su montaje. La violencia criminal y el deseo desenfrenado que la máquina orgiástica sadiana precipita en el árbol del crimen se conectan, así, con la carga libidinal y fantasmática de la imagen barroca de Loyola y el "psicodrama" de sus técnicas y sus ensamblajes, de sus arborescencias. Y si el "carácter obsesional" — no olvidemos la acusación sufrida por Las Casas de ser víctima no solamente de un delirio paranoico sino asimismo de padecer una "neurosis obsesiva"-, si la obsesión por la "contabilidad", en los Ejercicios, hace que "en cuanto aparece un objeto, intelectual o imaginario, es roto, dividido, enumerado", en el marco de "una contabilidad que es obsesional no solo porque es infinita, sino sobre todo porque engendra sus propias faltas" (Barthes 1977: 76), en la Brevísima hay también la presencia de este mismo recurso inverso de no solo acudir a lo infinito y a lo innumerable, sino de arrojarse a la inabarcabilidad de las exageraciones numéricas y de las desmesuras, y a la enumeración imaginaria de crímenes aún desconocidos. Pero las "imágenes" poseen, junto a esas potencias obsesivas, otras virtudes psicoterapéuticas:

Podemos decir que Ignacio se afana tanto para llenar el espíritu de imágenes como los místicos (cristianos y budistas) para vaciarlo de ellas; y si queremos referirnos a ciertas hipótesis actuales, que definen al enfermo psicosomático como un sujeto impotente para producir fantasmas y a la cura como un esfuerzo metódico para hacerle recobrar una "capacidad de manipulación fantasmática", Ignacio es en verdad un psicoterapeuta que busca, a cualquier precio, inyectar imágenes en el espíritu mate, seco y vacío del ejercitante (Barthes 1977: 75-76).

Y si extendemos hasta este punto la conexión lascasiana con esta técnica barroca de producción de "imágenes fantasmáticas", tendremos que concluir que también el autor de la Brevísima ejerce en ella un trabajo terapéutico, de curación a través de las imágenes - aunque sean esas imágenes crueles, de exorcismo o de conjuro, que se podrían vincular imaginariamente a los espectáculos soñados por Artaud en su "Teatro de la Crueldad"-

"Los Ejercicios", dice Barthes, citando a un comentador jesuita, "constituyen un lugar temible y deseable a la vez". Miedo y deseo son los polos, yuxtapuestos, como en la Brevísima - que apela a la compasión y al "terror" en su catarsis de excesos del deseo-, que la terapéutica barroca de la imagen (visual, sonora, olfativa, táctil) despliega, como "técnica", como performance, en su acción: "En efecto, quien lea los Ejercicios tiene que sentirse conmovido 
por la masa de deseo que allí se agita" (Barthes 1977: 68) —como en la orgía sadiana la voluntad de poder o la crueldad conquistadora-; la "fuerza inmediata" del deseo aparece "en la materialidad misma de los objetos" que exige la "representación" y que se expresa por ejemplo en los "lugares en su dimensión exacta", los "personajes con sus vestimentas, sus actitudes, sus acciones, sus palabras directas", confiriendo o imprimiendo a "las cosas más abstractas, invisibles", "algún movimiento material en que pintarse y terminar como cuadros vivos" - "suscitar", así, a la Trinidad bajo la forma de tres personas que miran "a los hombres que descienden al Infierno"- (68). Pero el fondo en que radica la "fuerza de la materialidad", la cifra inmediata del deseo es [...] el cuerpo humano: "corporeidad" del ejercitante que, sometido a una analogía literal -la "crítica" en los Ejercicios o la evangélica de los "lobos" y las "ovejas”, en la Brevísima-, le da cuerpo a otra existencia imaginaria transformada en "casi fisiológica" a través de la "anamnesis personal". Hay un "ascenso hacia la materia"; "el cuerpo no es nunca conceptual": "Si me transporto a un valle de lágrimas, tengo que imaginar, que ver esta piel, estos miembros entre los cuerpos de los [demás] animales, y percibir la infección que sale de este objeto misterioso" (69).

"Todo está hecho para que el ejercitante se represente a sí mismo en ese teatro", apunta Barthes: "es su cuerpo el que va a ocuparlo" (Barthes 1977: 69). Y si, a juicio del semiólogo, "la existencia deiforme - [de nuevo] según la notación de Ruysbroeck- ofrece la escena, el material anecdótico del fantasma" (69), podría decirse que en la Brevísima son las conquistas, la anónima "máquina" cruel de las guerras contra los indios, o la "existencia criminal" de los conquistadores las que ofrecen la escena y el "material del fantasma".13 Ese "boceto evangélico" — cifrado, aunque nunca agotado, en la inversión de la parábola de los lobos y las ovejas- ofrece el cuerpo al escenario fantasmal del deseo: la sucesión desenfrenada de escenas catárticas y extáticas de crueldad y violencia, proyecta al final ese "escenario", ese oscuro fantasma del deseo cuya "plasticidad absoluta", simbólica y metamórfica (70), se oculta, se ramifica y extiende, de manera invisible y secreta, en el árbol del crimen.

13 Barthes cita, aquí, la definición de "fantasma” según Laplanche y Pontalis: "El fantasma es 'un escenario imaginario donde el sujeto está presente, y que figura [...] la realización de un deseo"' (apud Barthes 1977: 84). 


\section{Bibliografía}

Agamben, Giorgio (2017). El uso de los cuerpos, trad. Rodrigo Molina Zavalía. Buenos Aires, Adriana Hidalgo.

Artaud, Antonin (2014). El teatro y su doble, trad. Silvio Mattoni. Buenos Aires, El Cuenco de Plata.

BARTHES, Roland (1977). Sade, Loyola, Fourier, trad. Néstor Leal. Caracas, Monte Ávila. BARTHES, Roland (1997). Sade, Loyola, Fourier, trad. Alicia Martorell. Madrid, Cátedra.

Blanchot, Maurice (1990). “La razón de Sade”, en Lautréamont y Sade, trad. Enrique Lombera Pallares. México, Fondo de Cultura Económica: 15-63.

DE BRY, Theodor (1992). América (1590-1634), pról. Hohn H. Elliot, ed. Gereon Sievernich, trad. Adán Kovacsics. Madrid, Siruela.

Diderot, Denis (2013). Suplemento al viaje de Bougainville, trad. Jaime Rosal. Madrid, Sd Edicions.

Flores, Enrique (2019). "Homo homini lupus: el Hombre de los Lobos", Inflexiones, núm. 5: 9-33.

Flores, Enrique (2021a). "Psycopathia lascasiana: un 'delirio paranoico', Literatura Mexicana, núm. XXXII-1.

FLORES, Enrique (2021b [en prensa]). "Zamé o la utopía”, LiminaR, núm. XIX-2 (juliodiciembre).

FrançOIS DE SADE, Donatien Alphonse (1979). Sistema de la agresión. Textos filosóficos y políticos, ed. Noelle Châtelet, trad. Rossend Arqués. Barcelona, Tusquets.

KLOssowski, Pierre (1970). Sade mi prójimo, trad. Graciela de Sola. Buenos Aires, Sudamericana.

LAS CASAS, Bartolomé de (1984). Brevísima relación de la destrucción de las Indias, ed. André Saint-Lu. Madrid, Cátedra.

Le Brun, Annie (2008). Sade. De pronto un bloque de abismo..., trad. Silvio Mattoni. Buenos Aires, El Cuenco de Plata.

MenÉndez PidAl, Ramón (1957). “Una norma anormal del padre Las Casas”, Cuadernos Hispanoamericanos, núm. 88 (abril): 5-15.

MenÉndez PidAl, Ramón (1963). El padre Las Casas: su doble personalidad. Madrid, Espasa Calpe.

YATES, Frances A. (1974). El arte de la memoria, trad. Ignacio González de Liaño. Madrid, Ariel.

\section{Enrique Flores Esquivel}

Doctor en Letras Hispánicas por El Colegio de México. Investigador en el Instituto de Investigaciones Filológicas y profesor de Literatura Colonial y Etnopoética en la Facultad de Filosofía y Letras de la Universidad Nacional Autónoma de México. Miembro del Sistema Nacional de Investigadores (SNI). Coordinó la Guía de Forasteros (INBA), el proyecto “Adugo biri: etnopoéticas” (UNAM), y actualmente: "Primitivismo y locura: poéticas de las vanguardias". 
Interpretatio, 6.1, marzo-agosto 2021: 135-158

Libros: Unipersonal del arcabuceado, La imagen desollada, Los tigres del miedo, El fin de la conquista, Malverde: exvotos y corridos, Rimas malandras, Nierika, Sor Juana chamana, Triumphos contra vandoleros, Gauchillaje entre demonios, Etnobarroco y Teatrum Chemichum. 